\title{
Growth Factors and Stem Cells for the Management of Anterior Cruciate Ligament Tears
}

\author{
Giacomo Rizzello ${ }^{1,2}$, Umile Giuseppe Longo ${ }^{*}, 1,2$, Stefano Petrillo ${ }^{1,2}$, Alfredo Lamberti ${ }^{1,2}$, \\ Wasim Sardar Khan ${ }^{3}$, Nicola Maffulli ${ }^{4}$ and Vincenzo Denaro ${ }^{1,2}$
}

\author{
${ }^{I}$ Department of Orthopaedic and Trauma Surgery. Campus Bio-Medico University, Via Alvaro del Portillo, 200, 00128 \\ Trigoria, Rome, Italy \\ ${ }^{2}$ Centro Integrato di Ricerca (CIR) Campus Bio-Medico University, Via Alvaro del Portillo, 21, 00128, Rome, Italy \\ ${ }^{3}$ University College London Institute of Orthopaedics and Musculoskeletal Sciences, Royal National Orthopaedic \\ Hospital, Stanmore, London, HA7 4LP, UK \\ ${ }^{4}$ Centre for Sports and Exercise Medicine, Barts and The London School of Medicine and Dentistry, Mile End Hospital, \\ 275 Bancroft Road, London, E1 4DG, UK
}

\begin{abstract}
The anterior cruciate ligament (ACL) is fundamental for the knee joint stability. ACL tears are frequent, especially during sport activities, occurring mainly in young and active patients. Nowadays, the gold standard for the management of ACL tears remains the surgical reconstruction with autografts or allografts. New strategies are being developed to resolve the problems of ligament grafting and promote a physiological healing process of ligamentous tissue without requiring surgical reconstruction. Moreover, these strategies can be applicable in association surgical reconstruction and may be useful to promote and accelerate the healing process. The use of growth factors and stem cells seems to offer a new and fascinating solution for the management of ACL tears. The injection of stem cell and/or growth factors in the site of ligamentous injury can potentially enhance the repair process of the physiological tissue. These procedures are still at their infancy, and more in vivo and in vitro studies are required to clarify the molecular pathways and effectiveness of growth factors and stem cells therapy for the management of ACL tears. This review aims to summarize the current knowledge in the field of growth factors and stem cells for the management of ACL tears.
\end{abstract}

Keywords: Anterior cruciate ligament, surgical reconstruction, stem cells, growth factors, repair.

\section{INTRODUCTION}

Ligaments are fibrous connective tissue bands that connect two or more bones. Ligaments are fundamental for joint stability and they provide resistance to forces to prevent excessive motion [1]. The ligamentous tissue volume is made of extracellular matrix (ECM) and fibroblasts for the $80 \%$ and $20 \%$ respectively. Several proteins compose the dry weight of a ligament, such as collagen (75\%), elastin (1\%), proteoglycans, and glycoproteins. $90 \%$ of the collagen is type I and 10\% is type III [2]. The role of fibroblasts is to secrete the ECM and to maintain, repair and regenerate new tissue growth [2]. Ligaments are able to sustain high mechanical loads while they present poor regeneration properties when they are injured $[3,4]$. Besides, they are repaired by a weaker and disorganized tissue which is prone to re-injury [5]. Growth factors and stem cells seem to play an important role in the process of ligament healing, but the

*Address correspondence to this author at the Department of Orthopaedic and Trauma Surgery, Campus Bio-Medico University, Via Alvaro del Portillo, 200, 00128 Trigoria, Rome, Italy; Centro Integrato di Ricerca (CIR) Campus Bio-Medico University, Via Alvaro del Portillo, 21, 00128, Rome, Italy; Tel.: + 39062254 11; Fax: + 3906225411934 ;

E-mail: g.longo@unicampus.it real molecular setting is not clearly understood $[4,5]$. In various studies was hypnotized that the lower cells density and vascularity, the lack of oxygen and the poor concentration of nutrients influence the healing of ligaments $[2-4,6,7]$.

The anterior cruciate ligament (ACL) is a fundamental ligament for the knee joint [8]. The ACL consists of two functional bundles: the antero-medial bundle (AMB) and postero-lateral bundle (PLB) [9, 10]. The AMB originates more proximally on the femoral site, and inserts anteromedially on the tibia. The PLB originates more distally on the femoral site, and inserts postero-laterally on the tibia [911]. The AMB and PLB are oriented nearly parallel with the knee extended, and twist around each other as the knee flexes [12].

Because the knee joint is subjected to high mechanical loads, especially during numerous sport activities, ACL is frequently injured [6, 13-15]. Despite the medial collateral ligament (MCL) of the knee, the injured ACL rarely heals and usually the surgical reconstruction is required to maintain a similar pre-injury physical activity $[3,16]$. Patients with injured ACL, mostly during sport activities, usually present recurrent instability of the knee joint [17], which could determine the development of early 
osteoarthritis [18]. Nowadays, the arthroscopic reconstruction using autografts remains the gold-standard for the management of ACL tears [19-22]. Autografts presents high mechanical strength and compatibility, with high revascularization and remodeling capacities [23]. However, several drawbacks can be associated with autografts, such as donor site morbidity and damage, pain and altered harvest site biomechanics [8, 24-26]. On the other hand, allografts exclude the risks of donor site morbidity and pain. However, they are associated with other important risks such as infection, allergic reactions and disease transmission [27-29]. In addition, according to various studies, allografts present lower early cellularity and less revascularization when compared with autografts [27-31].

Following these findings, several new strategies are investigated for ligament regeneration, such as the use of biomaterials, cell therapies, tissue engineering strategies and gene therapy, to promote a more functional and physiological healing of ligaments without requiring surgical reconstruction $[2,32-37]$. The aim of the present review is to summarize the role of growth factors and stem cells therapy for the management of ACL tears.

\section{GROWTH FACTORS}

Numerous studies demonstrated the role of growth factors in the healing process of ligaments. These growth factors, including insulin like growth factor I (IGF-I), transforming growth factor- $\beta$ (TGF- $\beta$ ), vascular endothelial growth factor (VEGF), basic fibroblast growth factor (bFGF), epidermal growth factor (EGF), and platelet derived growth factor (PDGF), were proved to be able to regulate the cellular activities, promote ligament cell proliferation and induce ECM to achieve the repair of ligaments tears $[5,38$ 43]. Moreover, they present the capacity to promote an anabolic state of ligamentous cells, improving the cell proliferation and ECM deposition, and may also influence the differentiation of mesenchymal stem cells (MSCs) into fibroblasts [2, 32, 33, 44-49].

According to previous studies observations, better results with the use of growth factors were obtained in the management of MCL tears [3, 16]. In fact, numerous studies conducted on rabbits showed that MCL fibroblasts are responsive to TGF- $\beta 1$ and EGF [50]. Moreover, TGF- $\beta 1$ and IGF-I were able to modify the metabolic and biochemical activity of ligamentous cells [51]. In addition, in another study was reported that the topical application of TGF- $\beta 1$, with or without the association of EGF, increased the ECM synthesis during ligamentous healing processes [52]. Similar results were obtained using PDGF [40]. Another study demonstrated that PDGF, bFGF, and IGF-I can stimulate cell proliferation in ligaments [43]. Kobayashi et al. [53], in a canine study, demonstrated that the application of bFGF enhances neovascularization and the formation of granulation tissue in injured ACL. Other authors, by using a mathematical method to analyze cell densities in a wound model in rabbits, showed that cells were able to migrate into cell-free areas of the ligament [54]. Several authors have observed that the combination of growth factors can have synergistic effects [39-41, 52]. DesRosiers et al. [38] found that the combination of EGF and PDGF had a better effect than TGF- $\beta 1$ and IGF-I concerning cell proliferation, while the proteoglycan production was increased by all four factors. Nevertheless, the TGF- $\beta 1$ presented the strongest effect regarding proteoglycan production [38]. In other studies, it was demonstrated that ligaments treated with a combination of PDGF plus IGF-I and PDGF plus bFGF presented increased rupture force, stiffness, and breaking energy [41], and that synergistic effect of combination of bFGF, TGF- $\beta 1$, bovine insulin and PDGF were associated with better outcomes than each individual factor [55]. In the last decades was proved that the use of platelet rich plasma (PRP) was able to improve the healing of ligaments. In fact, Liu et al. [56] demonstrated that the platelet concentration had a dose-response relationship with proliferation of MSCs such as fibroblasts. Following these findings, other authors considered the PRP as an effective agent for ligament healing [57-59], while in several studies it was concluded that the application of PRP was not associated with any advantage when performed with ACL reconstruction procedures [60-62].

In conclusion, various findings concerning the growth factors therapy are promoting their application in the human species for the management of ACL lesions. Therefore, many aspects remain to be clarified, such as their use or not in association with surgical reconstruction or in complete ACL tears. More in vitro and in vivo studies, especially randomized trials conducted in a strict scientific fashion, are required to really understand the role and efficacy of growth factors for the management of ACL tears.

\section{STEM CELLS}

Nowadays, the use of stem cells in orthopedics practices and related researches is largely improved [63-66]. Numerous studies focused their attention on MSCs, adipose derived stem cells (ASCs) and primary fibroblasts derived from ligaments (PFLs) for the regeneration of ligamentous lesions [32-35, 44, 45, 67-70].

Adult stem cells are also called non-embryonic stem cells (non-ESC), and are usually obtained from the bone marrow. There are two types of non-ESC available: haemopoietic, which generate the blood cells, and MSCs. The MSCs present the capacity to proliferate, differentiate in several tissues and regenerate tissues in case of lesions. Moreover, they present the capacity to secrete soluble factors which can alter the tissue microenvironment in order to repair tissues. Several cytokines and chemokines guide the MSCs to the zone of tissue injury, completing the also called homing process, to allow tissue repair and regeneration, while the molecular mechanism of the mobilization of MSCs from the bone marrow is not clearly understood. The MSCs of the bone marrow have a greater capacity to differentiate in several tissues when compared with other MSCs of different tissue origin, and the bone marrow aspiration is considered the most useful procedure to acquire MSCs. However, several complications are associated with bone marrow aspiration such as pain, infection and increased risks of morbidity. Following these findings, other sources of MSCs have been investigated such as synovium, adipose tissue and tendon $[67,68]$, but their differentiation and regenerative capacities are not clearly defined [71,72].

The MSCs are the most used for ligament tissue engineering. This trend is linked to the capacity of MSCs to 
easily differentiate into ligament fibroblasts after few weeks [2, 6, 32-34, 44, 69, 73-75]. Traditionally, MSCs have been extracted from bone marrow and other sources such as adipose tissue and synovial fluid [48, 70]. Moreover, the number of MSCs is known to increase following any ligament injury and in degenerative disorders such as osteoarthritis [76]. In a large animal model study involving pigs, the MSCs demonstrated the exhibition of fibroblast phenotype and the capacity to differentiate at 24 weeks postoperatively with the association of silk-based scaffolds [33]. Lim et al. [77] performed ACL reconstructions in adult rabbits using hamstring tendon autografts that were associated with MSC by means of fibrin glue carrier. After 8 weeks, better osteointegration and biomechanical properties were observed in the study group than the control group. On the other hand, in another study conducted on rabbits, the MSC have been shown to have stopped proliferation, increased in size and assumed an irregular morphology at 25-30 days after surgical transplantation [34]. Oe et al. [35] conducted a study on rats following intra-articular injection of either fresh bone marrow cells (BMC) or cultured MSCs, 1 week after partial ACL transection. The authors found that, after 4 weeks, donor cells were located within the transected $\mathrm{ACL}$ in both the BMC and MSC groups. Moreover, the ACL exhibited almost normal histology and more mature spindle cells, while higher levels of TGF- $\beta$ were found in the ACL tissue of the BMC group. At the end, they concluded that the direct intra-articular BMC transplantation can be an effective solution for the management of partial ruptures of the ACL [35]. Similar results using intra-articular injections have been reported by other researchers [78]. However, these results were obtained in animal studies performed in partial ACL tears. On the other hand, Cheng et al. reported better outcomes from the stem cells derived from the ACL itself compared to bone-marrow derived MSCs [79].

Co-cultures are rapidly becoming popular to promote MSCs differentiation by growing them together with fibroblasts [80, 81]. The molecular mechanism of action is based on the cytokines released within the 3-dimensional environment and on the cell-to-cell interactions between the fibroblasts and MSCs. Nevertheless, in one study was proved that the fascia wrapped around the MSC-seeded ACL tissue construct was useful to promote ECM production while did not enhance the physiological tensile load and stiffness [82].

Recently, the use of several techniques and substances, called bioreactors, were largely used in the orthopedic research in association with MSCs [83-87]. Bioreactors can be chemical, mechanical, electrical, or magnetic, and had demonstrated the ability to promote and accelerate the differentiation process of MSCs into fibroblasts [85]. The chemical stimulation technique consists on the use of growth factors $[38-43,49,50,52,74,88-90]$. The major problem associated with this procedure was the possibility to maintain sufficient quantities of growth factor within the local tissue. To resolve this pitfall, the gene transfer technology has been introduced in association with growth factors injection [91]. Wei et al. transfected the bone-marrow-derived MSC with adenovirus vector encoding TGF- $\beta 1$, VEGF, or TGF$\beta 1 / \mathrm{VEGF}$ before surgical implantation into experimental ACL grafts [92], finding an immediate improvement of angiogenesis and excellent mechanical properties 24 weeks after surgery. Mechanical stimulation is another method used to induce the differentiation of MSCs into the fibroblast phenotype. The trigger of the cell surface stretch receptors determines the activation of the anabolic phenotype of the cells, resulting in improving synthesis of ECM proteins [9395]. Altman et al. [94], by using a specialized bioreactor, observed that helically organized collagen fibers were formed in the direction of the load.

In summary, MSCs can be considered a possible solution to regenerate injured ligaments. Numerous advantages are associated with the MSCs injection in ACL tears including: the use of autologous cells, the ability to differentiate into fibroblasts and secrete the ECM, the capacity to regenerate a ligamentous tissue without requiring surgical intervention. Nevertheless, better results were obtained in MCL or in partial ACL tears. Co-cultures, such as bioreactors, can be a possible solution to improve MSCs differentiation and proliferation capacities. Besides, the use of bioreactors, especially growth factors and mechanical stress, in association with MSCs, can be considered an available technique to promote the MSCs differentiation into fibroblasts cells, achieving a physiological ligamentous tissue with good molecular and biomechanical properties.

\section{CONCLUSIONS}

The use of growth factors offers a promising solution for the management of ACL tears, especially in young and active patients. According to our literature review, better results were obtained in the treatment of MCL or ACL partial tears. Several advantageous outcomes are linked with the intra-articular injection of growth factors, such as ligamentous cells proliferation, ECM deposition and the MSCs differentiation into ligament fibroblasts cells [2, 32, 33 , 44-49]. Furthermore, the use of growth factors in association with MSCs offers several well-known advantages, fully demonstrated in various in vivo and in vitro studies.

On the other hand, the MSCs can be considered an effective solution for the management of ACL tears, associated with several benefits such as the use of autologous cells, the ability to differentiate into fibroblasts at around 2-4 weeks and the relative ease of procurement. Moreover, the MSCs demonstrated the capacity to secrete the ECM and regenerate ligamentous tissue when injuries occurred. Finally, the use of co-cultures and bioreactors can be useful to accelerate and promote the differentiation process of MSCs into fibroblasts.

The application of growth factors and MSCs for the treatment of ACL tears in the human species seems fascinating such as premature, but also possible in the very near future. Further in vivo studies, especially randomized trials on large animal models, are required to clarify the effectiveness of growth factors and MSCs for the management of ACL tears.

\section{CONFLICT OF INTEREST}

The authors confirm that this article content has no conflict of interest.

\section{ACKNOWLEDGEMENTS}

Declared none. 


\section{REFERENCES}

[1] Woo SL, Chan SS, Yamaji T. Biomechanics of knee ligament healing, repair and reconstruction. J Biomech 1997; 30: 431-9.

[2] Hoffmann A, Gross G. Tendon and ligament engineering in the adult organism: mesenchymal stem cells and gene-therapeutic approaches. Int Orthop 2007; 31: 791-7.

[3] Woo SL, Niyibizi C, Matyas J, Kavalkovich K, Weaver-Green C, Fox RJ. Medial collateral knee ligament healing. Combined medial collateral and anterior cruciate ligament injuries studied in rabbits. Acta Orthop Scand 1997; 68: 142-8.

[4] Woo SL, Debski RE, Zeminski J, Abramowitch SD, Saw SS, Fenwick JA. Injury and repair of ligaments and tendons. Annu Rev Biomed Eng 2000; 2: 83-118.

[5] Molloy T, Wang Y, Murrell G. The roles of growth factors in tendon and ligament healing. Sports Med 2003; 33: 381-94.

[6] Woo SL, Vogrin TM, Abramowitch SD. Healing and repair of ligament injuries in the knee. J Am Acad Orthop Surg 2000; 8: 364-72.

[7] Woo SL, Fisher MB, Feola AJ. Contribution of biomechanics to management of ligament and tendon injuries. Mol Cell Biomech 2008; 5: 49-68.

[8] Beynnon BD, Fleming BC, Churchill DL, Brown D. The effect of anterior cruciate ligament deficiency and functional bracing on translation of the tibia relative to the femur during nonweightbearing and weightbearing. Am J Sports Med 2003; 31: 99-105.

[9] Zelle BA, Brucker PU, Feng MT, Fu FH. Anatomical doublebundle anterior cruciate ligament reconstruction. Sports Med 2006; 36: 99-108.

[10] Girgis FG, Marshall JL, Monajem A. The cruciate ligaments of the knee joint. Anatomical, functional and experimental analysis. Clin Orthop Relat Res 1975; 106: 216-31.

[11] Dienst M, Burks RT, Greis PE. Anatomy and biomechanics of the anterior cruciate ligament. Orthop Clin North Am 2002; 33: 60520.

[12] Crawford C, Nyland J, Landes S, et al. Anatomic double bundle ACL reconstruction: a literature review. Knee Surg Sports Traumatol Arthrosc 2007; 15(8): 946-64.

[13] Maffulli N, Longo UG, Denaro V. Anterior cruciate ligament tear. N Engl J Med 2009; 360: 1463; author reply 1463.

[14] Forriol F, Longo UG, Hernández-Vaquero D, et al. The effects of previous meniscus and anterior cruciate ligament injuries in patients with total knee arthroplasty. Ortop Traumatol Rehabil 2010; 12: 50-7.

[15] Maffulli N, Longo UG, Gougoulias N, Loppini M, Denaro V. Long-term health outcomes of youth sports injuries. Br J Sports Med 2010; 44: 21-5.

[16] Bray RC, Leonard CA, Salo PT. Correlation of healing capacity with vascular response in the anterior cruciate and medial collateral ligaments of the rabbit. J Orthop Res 2003; 21: 1118-23.

[17] Frank CB, Jackson DW. The science of reconstruction of the anterior cruciate ligament. J Bone Joint Surg Am 1997; 79: 155676.

[18] Barrack RL, Bruckner JD, Kneisl J, Inman WS, Alexander AH. The outcome of nonoperatively treated complete tears of the anterior cruciate ligament in active young adults. Clin Orthop Relat Res 1990; 259: 192-9.

[19] Beynnon BD, Johnson RJ, Abate JA, Fleming BC, Nichols CE. Treatment of anterior cruciate ligament injuries, part 2. Am J Sports Med 2005; 33: 1751-67.

[20] Beynnon BD, Johnson RJ, Abate JA, Fleming BC, Nichols CE. Treatment of anterior cruciate ligament injuries, part I. Am J Sports Med 2005; 33: 1579-602.

[21] Capuano L, Hardy P, Longo UG, Denaro V, Maffulli N. No difference in clinical results between femoral transfixation and biointerference screw fixation in hamstring tendon ACL reconstruction. A preliminary study. Knee 2008; 15: 174-9.

[22] Franceschi F, Longo UG, Ruzzini L, Papalia R, Maffulli N, Denaro V. Quadriceps tendon-patellar bone autograft for anterior cruciate ligament reconstruction: a technical note. Bull NYU Hosp Jt Dis 2008; 66: 120-3.

[23] Janssen RP, van der Wijk J, Fiedler A, Schmidt T, Sala HA, Scheffler SU. Remodelling of human hamstring autografts after anterior cruciate ligament reconstruction. Knee Surg Sports Traumatol Arthrosc 2011; 19: 1299-306.
[24] Sachs RA, Daniel DM, Stone ML, Garfein RF. Patellofemoral problems after anterior cruciate ligament reconstruction. Am J Sports Med 1989; 17: 760-5

[25] Barrett GR, Noojin FK, Hartzog CW, Nash CR. Reconstruction of the anterior cruciate ligament in females: A comparison of hamstring versus patellar tendon autograft. Arthroscopy 2002; 18: 46-54.

[26] Barrett GR, Luber K, Replogle WH, Manley JL. Allograft anterior cruciate ligament reconstruction in the young, active patient: Tegner activity level and failure rate. Arthroscopy 2010; 26: 1593601 .

[27] Jackson DW, Grood ES, Goldstein JD, et al. A comparison of patellar tendon autograft and allograft used for anterior cruciate ligament reconstruction in the goat model. Am J Sports Med 1993; 21: 176-85.

[28] Li H, Tao H, Cho S, Chen S, Yao Z. Difference in graft maturity of the reconstructed anterior cruciate ligament 2 years postoperatively: a comparison between autografts and allografts in young men using clinical and 3.0-t magnetic resonance imaging evaluation. Am J Sports Med 2012; 40(7): 1519-26.

[29] Pallis M, Svodoba SJ, Cameron KL, Owens BD. Survival Comparison of Allograft and Autograft Anterior Cruciate Ligament Reconstruction at the United States Military Academy. Am J Sports Med 2012; 40(6): 1242-6.

[30] Longo UG, Buchmann S, Franceschetti E, Maffulli N, Denaro V. A systematic review of single-bundle versus double-bundle anterior cruciate ligament reconstruction. Br Med Bull 2011; 103: 147-68.

[31] Maffulli N, Spiezia F, King JB, Longo UG, Denaro V. Figure-offour pivot shift test--a technical note. Bull NYU Hosp Jt Dis 2011; 69: 173-6.

[32] Fan H, Liu H, Wong EJ, Toh SL, Goh JC. In vivo study of anterior cruciate ligament regeneration using mesenchymal stem cells and silk scaffold. Biomaterials 2008; 29: 3324-37.

[33] Fan H, Liu H, Toh SL, Goh JC. Anterior cruciate ligament regeneration using mesenchymal stem cells and silk scaffold in large animal model. Biomaterials 2009; 30: 4967-77.

[34] Ge Z, Goh JC, Lee EH. Selection of cell source for ligament tissue engineering. Cell Transplant 2005; 14: 573-83.

[35] Oe K, Kushida T, Okamoto N, et al. New strategies for anterior cruciate ligament partial rupture using bone marrow transplantation in rats. Stem Cells Dev 2011; 20: 671-9.

[36] Longo UG, Lamberti A, Maffulli N, Denaro V. Tendon augmentation grafts: a systematic review. Br Med Bull 2010; 94: $165-88$.

[37] Longo UG, Lamberti A, Maffulli N, Denaro V. Tissue engineered biological augmentation for tendon healing: a systematic review. Br Med Bull 2011; 98: 31-59.

[38] Desrosiers EA, Rivard CH, Bourdeau I, Yahia LH. Culture of fibroblasts of canine anterior cruciate ligaments in a defined medium, effect of epidermal growth factors and platelet derived growth factors. Ann Chir 1993; 47: 874-80.

[39] DesRosiers EA, Yahia L, Rivard CH. Proliferative and matrix synthesis response of canine anterior cruciate ligament fibroblasts submitted to combined growth factors. J Orthop Res 1996; 14: 2008.

[40] Hildebrand KA, Woo SL, Smith DW, et al. The effects of plateletderived growth factor-BB on healing of the rabbit medial collateral ligament. An in vivo study. Am J Sports Med 1998; 26: 549-54.

[41] Letson AK, Dahners LE. The effect of combinations of growth factors on ligament healing. Clin Orthop Relat Res 1994: 308: 20712.

[42] Scherping SC, Schmidt CC, Georgescu HI, Kwoh CK, Evans CH, Woo SL. Effect of growth factors on the proliferation of ligament fibroblasts from skeletally mature rabbits. Connect Tissue Res 1997; 36: 1-8.

[43] Schmidt CC, Georgescu HI, Kwoh CK, et al. Effect of growth factors on the proliferation of fibroblasts from the medial collateral and anterior cruciate ligaments. J Orthop Res 1995; 13: 184-90.

[44] Fan H, Liu H, Toh SL, Goh JC. Enhanced differentiation of mesenchymal stem cells co-cultured with ligament fibroblasts on gelatin/silk fibroin hybrid scaffold. Biomaterials 2008; 29: 101727.

[45] Kuo CK, Tuan RS. Tissue engineering with mesenchymal stem cells. IEEE Eng Med Biol Mag 2003; 22: 51-6.

[46] Kuo CK, Marturano JE, Tuan RS. Novel strategies in tendon and ligament tissue engineering: Advanced biomaterials and 
regeneration motifs. Sports Med Arthrosc Rehabil Ther Technol 2010;2: 20 .

[47] Moreau JE, Chen J, Bramono DS, et al. Growth factor induced fibroblast differentiation from human bone marrow stromal cells in vitro. J Orthop Res 2005; 23: 164-74.

[48] Sahoo S, Toh SL, Goh JC. A bFGF-releasing silk/PLGA-based biohybrid scaffold for ligament/tendon tissue engineering using mesenchymal progenitor cells. Biomaterials 2010; 31: 2990-8.

[49] Sahoo S, Ang LT, Cho-Hong Goh J, Toh SL. Bioactive nanofibers for fibroblastic differentiation of mesenchymal precursor cells for ligament/tendon tissue engineering applications. Differentiation 2010; 79: 102-10.

[50] Deie M, Marui T, Allen CR, et al. The effects of age on rabbit MCL fibroblast matrix synthesis in response to TGF-beta 1 or EGF. Mech Ageing Dev 1997; 97: 121-30.

[51] Murphy PG, Loitz BJ, Frank CB, Hart DA. Influence of exogenous growth factors on the synthesis and secretion of collagen types I and III by explants of normal and healing rabbit ligaments. Biochem Cell Biol 1994; 72: 403-9.

[52] Marui T, Niyibizi C, Georgescu HI, Cao M, Kavalkovich KW, Levine RE, et al. Effect of growth factors on matrix synthesis by ligament fibroblasts. J Orthop Res 1997; 15: 18-23.

[53] Kobayashi D, Kurosaka M, Yoshiya S, Mizuno K. Effect of basic fibroblast growth factor on the healing of defects in the canine anterior cruciate ligament. Knee Surg Sports Traumatol Arthrosc 1997; 5: 189-94.

[54] Kobayashi K, Healey RM, Sah RL, et al. Novel method for the quantitative assessment of cell migration: a study on the motility of rabbit anterior cruciate (ACL) and medial collateral ligament (MCL) cells. Tissue Eng 2000; 6: 29-38.

[55] Lee J, Green MH, Amiel D. Synergistic effect of growth factors on cell outgrowth from explants of rabbit anterior cruciate and medial collateral ligaments. J Orthop Res 1995; 13: 435-41.

[56] Liu Y, Kalén A, Risto O, Wahlström O. Fibroblast proliferation due to exposure to a platelet concentrate in vitro is $\mathrm{pH}$ dependent. Wound Repair Regen 2002; 10: 336-40.

[57] Joshi SM, Mastrangelo AN, Magarian EM, Fleming BC, Murray MM. Collagen-platelet composite enhances biomechanical and histologic healing of the porcine anterior cruciate ligament. Am J Sports Med 2009; 37: 2401-10.

[58] Radice F, Yánez R, Gutiérrez V, Rosales J, Pinedo M, Coda S. Comparison of magnetic resonance imaging findings in anterior cruciate ligament grafts with and without autologous plateletderived growth factors. Arthroscopy 2010; 26: 50-7.

[59] Cheng M, Wang H, Yoshida R, Murray MM. Platelets and plasma proteins are both required to stimulate collagen gene expression by anterior cruciate ligament cells in three-dimensional culture. Tissue Eng Part A 2010; 16: 1479-89.

[60] Silva A, Sampaio R. Anatomic ACL reconstruction: does the platelet-rich plasma accelerate tendon healing? Knee Surg Sports Traumatol Arthrosc 2009; 17: 676-82.

[61] Spindler KP, Murray MM, Carey JL, Zurakowski D, Fleming BC. The use of platelets to affect functional healing of an anterior cruciate ligament (ACL) autograft in a caprine ACL reconstruction model. J Orthop Res 2009; 27: 631-8.

[62] Nin JR, Gasque GM, Azcárate AV, Beola JD, Gonzalez MH. Has platelet-rich plasma any role in anterior cruciate ligament allograft healing? Arthroscopy 2009; 25: 1206-13.

[63] Longo UG, Lamberti A, Petrillo S, Maffulli N, Denaro V. Scaffolds in tendon tissue engineering. Stem Cells Int 2012; 2012: 517165.

[64] Longo UG, Petrillo S, Franceschetti E, Berton A, Maffulli N, Denaro V. Stem cells and gene therapy for cartilage repair. Stem Cells Int 2012; 2012: 168385 .

[65] Longo UG, Papapietro N, Petrillo S, Franceschetti E, Maffulli N, Denaro V. Mesenchymal stem cell for prevention and management of intervertebral disc degeneration. Stem Cells Int 2012; 2012: 921053.

[66] Longo UG, Petrillo S, Franceschetti E, Maffulli N, Denaro V. Growth factors and anticatabolic substances for prevention and management of intervertebral disc degeneration. Stem Cells Int 2012; 2012: 12 .

[67] Fossett E, Khan WS, Longo UG, Smitham PJ. Effect of age and gender on cell proliferation and cell surface characterization of synovial fat pad derived mesenchymal stem cells. J Orthop Res 2012; 30(7): 1013-8
[68] Khan WS, Adesida AB, Tew SR, Longo UG, Hardingham TE. Fat pad-derived mesenchymal stem cells as a potential source for cellbased adipose tissue repair strategies. Cell Prolif 2012; 45: 111-20.

[69] Liu H, Fan H, Toh SL, Goh JC. A comparison of rabbit mesenchymal stem cells and anterior cruciate ligament fibroblasts responses on combined silk scaffolds. Biomaterials 2008; 29: 144353.

[70] McGonagle D, Jones E. A potential role for synovial fluid mesenchymal stem cells in ligament regeneration. Rheumatology (Oxford) 2008; 47: 1114-6.

[71] Khaled EG, Saleh M, Hindocha S, Griffin M, Khan WS. Tissue engineering for bone production- stem cells, gene therapy and scaffolds. Open Orthop J 2011; 5 (Suppl 2): 289-95.

[72] Mafi R, Hindocha S, Mafi P, Griffin M, Khan WS. Sources of adult mesenchymal stem cells applicable for musculoskeletal applications - a systematic review of the literature. Open Orthop J 2011; 5 Suppl 2: 242-8.

[73] Woo SL, Hildebrand K, Watanabe N, Fenwick JA, Papageorgiou $\mathrm{CD}$, Wang $\mathrm{JH}$. Tissue engineering of ligament and tendon healing. Clin Orthop Relat Res 1999: 367 (Suppl): S312-23.

[74] Hoffmann A, Gross G. Tendon and ligament engineering: from cell biology to in vivo application. Regen Med 2006; 1: 563-74.

[75] Arthur A, Zannettino A, Gronthos S. The therapeutic applications of multipotential mesenchymal/stromal stem cells in skeletal tissue repair. J Cell Physiol 2009; 218: 237-45.

[76] Morito $\mathrm{T}$, Muneta $\mathrm{T}$, Hara $\mathrm{K}$, et al. Synovial fluid-derived mesenchymal stem cells increase after intra-articular ligament injury in humans. Rheumatology (Oxford) 2008; 47: 1137-43.

[77] Lim JK, Hui J, Li L, Thambyah A, Goh J, Lee EH. Enhancement of tendon graft osteointegration using mesenchymal stem cells in a rabbit model of anterior cruciate ligament reconstruction. Arthroscopy 2004; 20: 899-910.

[78] Kanaya A, Deie M, Adachi N, Nishimori M, Yanada S, Ochi M. Intra-articular injection of mesenchymal stromal cells in partially torn anterior cruciate ligaments in a rat model. Arthroscopy 2007; 23: 610-7.

[79] Cheng MT, Liu CL, Chen TH, Lee OK. Comparison of potentials between stem cells isolated from human anterior cruciate ligament and bone marrow for ligament tissue engineering. Tissue Eng Part A 2010; 16: 2237-53.

[80] Ball SG, Shuttleworth AC, Kielty CM. Direct cell contact influences bone marrow mesenchymal stem cell fate. Int J Biochem Cell Biol 2004; 36: 714-27.

[81] Lee IC, Wang JH, Lee YT, Young TH. The differentiation of mesenchymal stem cells by mechanical stress or/and co-culture system. Biochem Biophys Res Commun 2007; 352: 147-52.

[82] Ge Z, Goh JC, Lee EH. The effects of bone marrow-derived mesenchymal stem cells and fascia wrap application to anterior cruciate ligament tissue engineering. Cell Transplant 2005; 14: 763-73.

[83] Lavrentieva A, Hatlapatka T, Neumann A, Weyand B, Kasper C. Potential for osteogenic and chondrogenic differentiation of MSC. Adv Biochem Eng Biotechnol 2012 [Epub ahead of Print].

[84] Mabvuure N, Hindocha S, Khan WS. The role of bioreactors in cartilage tissue engineering. Curr Stem Cell Res Ther 2012; 7(4): 287-94.

[85] Oragui E, Nannaparaju M, Khan WS. The role of bioreactors in tissue engineering for musculoskeletal applications. Open Orthop J 2011; 5 (Suppl 2): 267-70.

[86] Yates EW, Rupani A, Foley GT, Khan WS, Cartmell S, Anand SJ. Ligament tissue engineering and its potential role in anterior cruciate ligament reconstruction. Stem Cells Int 2012; 2012 : 438125.

[87] Yilgor C, Yilgor Huri P, Huri G. Tissue engineering strategies in ligament regeneration. Stem Cells Int 2012; 2012: 374676.

[88] Forriol F, Longo UG, Concejo C, Ripalda P, Maffulli N, Denaro V. Platelet-rich plasma, rhOP-1 (rhBMP-7) and frozen rib allograft for the reconstruction of bony mandibular defects in sheep. A pilot experimental study. Injury 2009; 40 (Suppl 3): S44-9.

[89] Moreau JE, Chen J, Horan RL, Kaplan DL, Altman GH. Sequential growth factor application in bone marrow stromal cell ligament engineering. Tissue Eng 2005; 11: 1887-97.

[90] Sahoo S, Ang LT, Goh JC, Toh SL. Growth factor delivery through electrospun nanofibers in scaffolds for tissue engineering applications. J Biomed Mater Res A 2010; 93: 1539-50. 
[91] Kanitkar M, Tailor HD, Khan WS. The use of growth factors and mesenchymal stem cells in orthopaedics. Open Orthop J 2011; 5 (Suppl 2): 271-5.

[92] Wei X, Mao Z, Hou Y, et al. Local administration of TGFß1/VEGF165 gene-transduced bone mesenchymal stem cells for Achilles allograft replacement of the anterior cruciate ligament in rabbits. Biochem Biophys Res Commun 2011; 406: 204-10.
[93] Altman GH, Lu HH, Horan RL, et al. Advanced bioreactor with controlled application of multi-dimensional strain for tissue engineering. J Biomech Eng 2002; 124: 742-9.

[94] Altman GH, Horan RL, Martin I, et al. Cell differentiation by mechanical stress. FASEB J 2002; 16: 270-2.

[95] Moreau JE, Bramono DS, Horan RL, Kaplan DL, Altman GH. Sequential biochemical and mechanical stimulation in the development of tissue-engineered ligaments. Tissue Eng Part A 2008; 14: 1161-72.

Received: July 14, 2012

Revised: September 14, 2012

Accepted: September 22, 2012

(C) Rizzello et al.; Licensee Bentham Open.

This is an open access article licensed under the terms of the Creative Commons Attribution Non-Commercial License (http://creativecommons.org/licenses/by-nc/3.0/) which permits unrestricted, non-commercial use, distribution and reproduction in any medium, provided the work is properly cited. 